\title{
Modeling hydraulic properties of sandy soils of Niger using pedotransfer functions
}

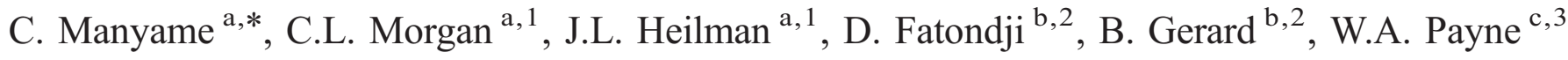 \\ ${ }^{a}$ MidSouth Synergy, 7625 HWY 6, Navasota TX 77868, United States \\ ${ }^{\mathrm{b}}$ ICRISAT Sahelian Center, BP 12404, Niamey, Niger \\ c Texas A\&M University Agricultural Research and Extension Center, 2301 Experiment Station Road, Bushland, TX 79012, United States
}

Received 21 October 2006; received in revised form 18 March 2007; accepted 3 July 2007

Available online 9 August 2007

\begin{abstract}
Direct determination of soil hydraulic properties is often costly and laborious hence the use of indirect methods such as pedotransfer functions (PTFs). Despite progress made in PTF development in general, little evaluation of PTFs has been done for the sandy soils of Niger. We tested the ability of three PTFs, (Campbell, van Genuchten, and Vauclin) to determine soil water retention and unsaturated hydraulic conductivity ( $K$ ) for sandy soils at two villages (Banizoumbou and Bagoua) in Niger. Modeled $K$ was compared to $K$ estimated from neutron probe readings at 1.4 m; and modeled moisture retention was compared to lab measurements derived from the hanging water column method and pressure plate apparatus for the following depth intervals: 0-30, 30-60, and $>60 \mathrm{~cm}$ at Banizoumbou; and 0-30, 30-120, and >120 cm at Bagoua. The Campbell PTF resulted in lower root mean square error (RMSE) $\left(0.05-0.06 \mathrm{~m}^{3} \mathrm{~m}^{-3}\right)$ for soil moisture retention for the three depth intervals at the two sites and performed better than the van Genuchten function (RMSE 0.06-0.07 $\mathrm{m}^{3} \mathrm{~m}^{-3}$ ) for Bagoua soils which had higher sand content. The van Genuchten PTF consistently overestimated dry regime moisture retention for the three depth intervals especially at Bagoua but performed well for the wet regime. The Campbell and Vauclin PTFs underestimated $K$ (RMSE 0.61-1.01 $\mathrm{mm} \mathrm{d}^{-1}$ ) at both sites whereas the van Genuchten model was close to field measurements (RMSE $0.26-0.47 \mathrm{~mm} \mathrm{~d}^{-1}$ ). These results show that the Campbell model is a cheaper alternative to direct measurement of moisture retention and the van Genuchten function can be used to estimate $K$ for Niger's sandy soils with modest accuracy.

(C) 2007 Elsevier B.V. All rights reserved.
\end{abstract}

Keywords: Hydraulic conductivity; Pedotransfer functions; Niger; Modelling; Moisture retention curve

\section{Introduction}

Soil hydraulic properties such as the moisture retention curve and hydraulic conductivity $(K)$ control storage and flux of water in soil making them crucial input parameters in water and solute transport modeling. Knowledge of these properties is needed in many field studies dealing with irrigation and drainage management. Field determination of $K$ and moisture retention curves is often laborious and costly (van Genuchten and Leij,

Abbreviations: $K$, hydraulic conductivity; Ks, saturated hydraulic conductivity; PTF, pedotransfer function; RMSE, root mean square error.

* Corresponding author. Tel.: +1 979204 2138; fax: +1 9368255166.

E-mail address: vamanyame@yahoo.com (C. Manyame).

${ }^{1}$ Tel.: +1 979845 3041; fax: +1 9798450456 .

2 Tel.: +22722529 .

3 Tel.: +1 806354 5801; fax: +1 8063545829 .
1992) while the $K$ values so determined do not capture the spatial variability under field conditions (Warrick and Nielsen, 1980; Wilding, 1984). This has led to the development and widespread use of indirect methods (Campbell, 1974; van Genuchten, 1980; Rawls et al., 1982; Haverkamp and Parlange, 1986; Vereecken et al., 1989; van Genuchten and Leij, 1992; Rawls et al., 1998; Elsenbeer, 2001; Sobieraj et al., 2001; Suleiman and Ritchie, 2001; Wösten et al., 2001) which are classified as pedotransfer functions (PTFs), which were intended to translate easily measured soil properties, like bulk density, particle size distribution, and organic matter content, into soil hydraulic properties.

PTFs can be categorized into three main groups namely class PTFs, continuous PTFs and neural networks (Schaap, 1999). Class PTFs calculate hydraulic properties for a textural class (e.g. sand) by assuming that similar soils have similar hydraulic 
properties; continuous PTFs on the other hand, use measured percentages of clay, silt, sand and organic matter content to provide continuously varying hydraulic properties across the textural triangle (Wösten et al., 1995). Neural networks are an "attempt to build a mathematical model that supposedly works in an analogous way to the human brain" (Minasny and McBratney, 2002) and were developed to improve the predictions of empirical PTFs (Schaap and Bouten, 1996; Sobieraj et al., 2001; Minasny and McBratney, 2002). In brief, a neural network consists of an input, a hidden, and an output layer all containing "nodes". The number of nodes in input (soil bulk density, soil particle size data) and output (soil hydraulic properties) layers corresponds to the number of input and output variables of the model (Schaap and Bouten, 1996). The major advantage of neural networks over the two groups of PTFs described earlier is that they do not require an a-priori concept of the relations between input and output data (Schaap and Leij, 1998). The optimal relations that link input data to output data are obtained and implemented in an iterative calibration procedure (Schaap et al., 2001).

An apparent limitation with the first group of PTFs is the fact that they provide an average value of a hydraulic characteristic for each textural class when, in fact, there may be a considerable range of values within a single textural class (Hodnett and Tomasella, 2002).

Some PTFs have been incorporated into standalone computer programs like ROSETTA (Schaap et al., 2001) and SOILPAR (Acutis and Donatelli, 2003). ROSETTA uses a neural network and bootstrap approach for parameter prediction and uncertainty analysis respectively while SOILPAR provides $15 \mathrm{PTF}$ procedures, classified as point and function PTFs, for parameter estimation. In SOILPAR, point PTFs estimate specific points of interest on the moisture retention curve and or Ks whereas function PTFs estimate the parameters of retention functions. Function PTFs implement the following four methods: (1) Rawls and Brakensiek (1989), to estimate Brooks and Corey (1964) function parameters; (2) Vereecken et al. (1989), to estimate van Genuchten (1980) function parameters; (3) Campbell (1985) to estimate Campbell function parameters (Campbell, 1974) and; (4) Mayr and Jarvis (1999), to estimate parameters of the Hutson and Cass (1987) modification of the Campbell function. These four methods require PSD and bulk density as input. The Mayr and Jarvis (1999), and Vereecken et al. (1989) methods also require organic carbon content as input. Unlike ROSETTA, SOILPAR does not perform uncertainty analysis for parameter estimation and hence we used it only to estimate the Campbell parameters which ROSETTA, on the other hand, does not estimate.

In general, the performance of PTFs has been shown to be largely dependant on the data used for their calibration (Schaap and Leij, 1998), and caution should always be exercised when using them. This is especially true if predictions are being made for soils that are outside the range of soils used in deriving the PTFs. This has been shown to lead to poor or even inaccurate predictions (Cornelis et al., 2001; Wagner et al., 2001; Wösten et al., 2001; Hodnett and Tomasella, 2002). Spatial variability in soil properties may also decrease the accuracy of predictions made by PTFs as has been shown for saturated hydraulic conductivity, Ks (Tietje and Hennings, 1996; Sobieraj et al., 2001).

Although progress has been made in the development and use of PTFs to estimate soil hydraulic properties in general, to our knowledge there has been very little evaluation of PTFs on the sandy soils of the West African Sahel. Substantial studies of soil hydraulic properties of these soils are available, however, (Vachaud et al., 1978; Hartmann and Gandah, 1982; Vauclin et al., 1983a; Payne et al., 1991) such that evaluation of PTFs for this region should be possible.

This study was carried out to evaluate the performance and suitability of some published PTF models for estimating the moisture retention and $K$-theta curves of sandy soils in the Fakara region of southwestern Niger. For moisture retention curves, we used the van Genuchten and Campbell models and for $K$-theta curves we used the van Genuchten, Campbell, and Vauclin models. We then compared both the moisture retention and $K$-theta curves estimated by the models to those previously published for sandy soils from Niger and or from the same region. The functional hydraulic properties so determined, would then be an important resource for modeling and understanding the water balance of farmers' fields in the Fakara.

The van Genuchten and Campbell PTF models were selected for this study because they have been widely used and evaluated for a wide range of soil types (Khaleel et al., 1995; Rockström et al., 1998; Schaap and Leij, 2000; Cornelis et al., 2001; Wagner et al., 2001; Amayreh et al., 2003). The Vauclin PTF model was originally developed for sandy soils of Senegal (Vauclin et al., 1983a) and later successfully used for Niger sandy soils with similar properties (Klaij and Vachaud, 1992). The direct method of estimating $K$ from neutron probe measurements (Green et al., 1986), as modified by Klaij and Vachaud (1992), was used as a reference to evaluate the reliability of the Vauclin, van Genuchten and Campbell PTFs in estimating $K$.

\section{Materials and methods}

\subsection{Pedotransfer models for soil moisture retention and hydraulic conductivity}

\subsubsection{The van Genuchten functions}

The van Genuchten (1980) moisture retention curve function can be represented by

$\theta(\psi)=\theta_{\mathrm{r}}+\left(\theta_{\mathrm{s}}-\theta_{\mathrm{r}}\right) /\left[1+(\alpha \psi)^{n}\right]^{1-1 / n}$,

where $\theta(\psi)$ is the measured volumetric water content $\left(\mathrm{cm}^{3}\right.$ $\left.\mathrm{cm}^{-3}\right)$ at suction $\psi(\mathrm{cm}) ; \theta_{\mathrm{r}}$ and $\theta_{\mathrm{s}}$ are residual and saturation moisture content respectively; $\alpha\left(\mathrm{cm}^{-1}\right)$ is related to the inverse of air entry suction. In Eq. (1), large values of $\alpha$ indicate conditions typical of sands, where very small negative heads empty pores creating a relatively large change in water content. The dimensionless $n$ controls the steepness of the S-shaped retention curve (Wösten et al., 1995). The van Genuchten moisture retention parameters, $\theta_{\mathrm{r}}, \theta_{\mathrm{s}}, \alpha$, and $n$ were estimated from field measured particle size and bulk density using ROSETTA software (Schaap et al., 2001). 
Combining Eq. (1) and Mualem's (1976) pore-size model results in the following expression for $K$ as a function of effective saturation $\left(S_{\mathrm{e}}\right)$ (van Genuchten, 1980)

$K\left(S_{\mathrm{e}}\right)=K_{\mathrm{o}} S_{\mathrm{e}}^{L}\left\{1-\left[1-S_{\mathrm{e}}^{n /(n-1)}\right]^{1-1 / n}\right\}^{2}$,

and $S_{\mathrm{e}}$, is

$S_{\mathrm{e}}=\theta(\psi)-\theta_{\mathrm{r}} /\left(\theta_{\mathrm{s}}-\theta_{\mathrm{r}}\right)$.

In Eq. (2), $K_{\mathrm{o}}\left(\mathrm{cm} \mathrm{d}^{-1}\right)$ is a fitted matching point at saturation which is similar but not necessarily equal to saturated hydraulic conductivity $K_{\mathrm{s}}$, while $L$ is an empirical parameter. The parameters $K_{\mathrm{o}}$ and $L$ were also estimated from field measurements of bulk density and soil particle size using ROSETTA (Schaap and Leij, 1998; Schaap et al., 2001).

\subsubsection{The Vauclin model}

The Vauclin model (Vauclin et al., 1983a) was derived from a study on Senegalese sandy soils with clay plus fine silt contents ranging from 3.5 to $12.0 \%$. Hydraulic conductivity values obtained from the instantaneous profile method (Watson, 1966) were used to model $K$ using the following function,

$K(\theta)=K_{\mathrm{o}}\left(\theta / \theta_{\mathrm{o}}\right)^{\beta}$,

where $K(\theta)\left(\mathrm{cm} \mathrm{h}^{-1}\right)$ is the hydraulic conductivity at moisture content $\theta\left(\mathrm{m}^{3} \mathrm{~m}^{-3}\right), K_{\mathrm{o}}\left(\mathrm{cm} \mathrm{h}^{-1}\right)$ is the hydraulic conductivity at final infiltration, $\beta$ is a dimensionless shape parameter and $\theta_{\mathrm{o}}$ $\left(\mathrm{m}^{3} \mathrm{~m}^{-3}\right)$ is the apparent saturated soil moisture content at final infiltration. The $\theta_{\mathrm{o}}$ value was taken as the lab measured moisture content at saturation, $\theta_{\mathrm{s}}$. The Vauclin $K_{\mathrm{o}}$ and $\beta$ parameters were calculated using the following functions,

$K_{\mathrm{o}}=28.42-1.5 .34($ Clay + FineSilt $)$

and

$\beta=3.67+0.437($ Clay + FineSilt $)$

where $K_{\mathrm{o}}$ is in $\mathrm{cm} \mathrm{h}^{-1}$, Clay is the clay content $(<2.0 \mu \mathrm{m}$ fraction, \%) and FineSilt is the fine silt content (2.0 to $20.0 \mu \mathrm{m}$ fraction, \%). The Vauclin model has been used in water balance studies on sandy soils in Nigeria (Grema and Hess, 1994), and in Niger (Klaij and Vachaud, 1992) yielding $K$ values very close to measured values.

\subsubsection{The Campbell models}

The Campbell equation for moisture retention is represented by

$\psi_{\mathrm{m}}=\psi_{\mathrm{e}}\left(\theta / \theta_{\mathrm{s}}\right)^{-b}$,

where $\theta$ is volumetric water content $\left(\mathrm{m}^{3} \mathrm{~m}^{-3}\right)$, and $\theta_{\mathrm{s}}$ is the saturation water content $\left(\mathrm{m}^{3} \mathrm{~m}^{-3}\right)$. The parameters $\psi_{\mathrm{m}}$ and $\psi_{\mathrm{e}}\left(-\mathrm{j} \mathrm{kg} \mathrm{kg}^{-1}\right)$ are soil matric potential and air entry water potential respectively and $b$ is the slope of $\log _{\mathrm{e}} \psi_{\mathrm{m}}$ vs. $\log _{\mathrm{e}} \theta$. Campbell and Norman (1998) also proposed a function for determining $K$ as

$K(\theta)=K_{\mathrm{s}}\left(\theta / \theta_{\mathrm{s}}\right)^{2 b+3}$,

where $K(\theta)$ and $K_{\mathrm{s}}$ are unsaturated and saturated hydraulic conductivities respectively, and $b$ is the same as in Eq. (7). Using field measured PSD and bulk density data, we estimated the Campbell model parameter values $\left(\psi_{\mathrm{e}}, K_{\mathrm{s}}\right.$, and $\left.b\right)$ using the Campbell PTF in SOILPAR (Acutis and Donatelli, 2003), while $\theta_{\mathrm{s}}$ was measured in the lab.

\subsection{Site description and soil sampling strategy}

The two study sites were Banizoumbou and Bagoua in the Fakara region of southwestern Niger. Banizoumbou is a village located at coordinates $13^{\circ} 31^{\prime} \mathrm{N}$ and $2^{\circ} 39^{\prime} \mathrm{E}, 65 \mathrm{~km}$ east of Niger's capital city, Niamey. The second village, Bagoua, is located at $2^{\circ} 46^{\prime} \mathrm{E}$ and $13^{\circ} 29^{\prime} \mathrm{N}, 12 \mathrm{~km}$ south east of Banizoumbou. The climate of the Fakara is hot and semi-arid with a unimodal rainfall distribution. Most of the rain falls between June and September, with an average of $500 \mathrm{~mm}$ (Le Barbe and Lebel, 1997). Soils in the study sites are classified as Psammentic Kandiustalfs (Soil Survey Staff, 1975; Heil et al., 1997) and pearl millet [Pennisetum glaucum (L.) Br.] is the major crop grown in the two villages. Soil sampling was done using a stratified random sampling method where a $90 \times 30 \mathrm{~m}$ plot was subdivided into three $30 \times 30 \mathrm{~m}$ subplots. For particle size distribution, soils were sampled randomly from each of these subplots using a push auger with $5 \mathrm{~cm}$ diameter, at the following depths: $0-30 \mathrm{~cm}$ at $10 \mathrm{~cm}$ intervals; and $30-210 \mathrm{~cm}$

Table 1

Particle size and bulk density data at Banizoumbou

\begin{tabular}{|c|c|c|c|c|c|c|c|c|c|c|c|c|}
\hline Depth & $2000-200 \mu \mathrm{m}$ & SE & $200-50 \mu \mathrm{m}$ & SE & $50-20 \mu \mathrm{m}$ & $\mathrm{SE}$ & $20-2 \mu \mathrm{m}$ & SE & $<2 \mu \mathrm{m}$ & $\mathrm{SE}$ & Bulk density & $\mathrm{SE}$ \\
\hline $\mathrm{cm}$ & $\mathrm{g} \mathrm{kg}^{-1}$ & & & & & & & & & & $\mathrm{~g} \mathrm{~cm}^{-3}$ & \\
\hline $0-10$ & 449.3 & 9.7 & 490.5 & 9.4 & 19.3 & 2.3 & 9.7 & 1.1 & 31.6 & 3.5 & 1.40 & 0.00 \\
\hline $10-20$ & 429.6 & 9.7 & 497.2 & 7.8 & 14.7 & 2.8 & 15.7 & 2.7 & 42.6 & 2.4 & 1.43 & 0.01 \\
\hline $20-30$ & 425.9 & 11.8 & 482.4 & 12.7 & 15.7 & 1.8 & 12.6 & 1.9 & 63.4 & 2.7 & 1.49 & 0.00 \\
\hline $30-60$ & 429.4 & 6.4 & 467.5 & 8.9 & 13.7 & 2.9 & 12.0 & 1.0 & 77.4 & 3.2 & 1.41 & 0.02 \\
\hline $60-90$ & 424.5 & 9.6 & 469.6 & 10.8 & 13.2 & 2.4 & 10.7 & 2.5 & 82.0 & 4.6 & 1.50 & 0.01 \\
\hline $90-120$ & 425.2 & 10.0 & 470.4 & 12.5 & 10.0 & 1.3 & 7.6 & 0.9 & 86.9 & 5.8 & 1.48 & 0.00 \\
\hline $120-150$ & 420.9 & 15.2 & 475.4 & 15.8 & 11.7 & 1.5 & 10.6 & 1.4 & 81.6 & 6.2 & 1.48 & 0.03 \\
\hline $150-180$ & 402.8 & 8.6 & 489.8 & 11.2 & 14.1 & 1.2 & 7.8 & 1.2 & 85.6 & 5.3 & 1.50 & 0.02 \\
\hline $180-210$ & 400.2 & 7.0 & 494.9 & 5.7 & 11.5 & 1.3 & 9.9 & 1.3 & 83.6 & 4.8 & 1.53 & 0.00 \\
\hline
\end{tabular}

Particle size data represents a mean of five cores.

SE, Standard error. 
Table 2

Particle size and bulk density data at Bagoua

\begin{tabular}{|c|c|c|c|c|c|c|c|c|c|c|c|c|}
\hline \multirow{2}{*}{$\frac{\text { Depth }}{\mathrm{cm}}$} & $2000-200 \mu \mathrm{m}$ & SE & $200-50 \mu \mathrm{m}$ & $\mathrm{SE}$ & $50-20 \mu \mathrm{m}$ & SE & $20-2 \mu \mathrm{m}$ & $\mathrm{SE}$ & $<2 \mu \mathrm{m}$ & SE & Bulk density & $\mathrm{SE}$ \\
\hline & \multicolumn{10}{|l|}{$\mathrm{g} \mathrm{kg}^{-1}$} & \multicolumn{2}{|l|}{$\mathrm{g} \mathrm{cm}^{-3}$} \\
\hline $0-10$ & 488.3 & 16.1 & 463.3 & 14.1 & 14.3 & 1.4 & 9.5 & 1.0 & 25.4 & 1.6 & 1.54 & 0.00 \\
\hline $10-20$ & 471.8 & 6.9 & 469.2 & 6.4 & 14.0 & 0.8 & 9.3 & 0.8 & 35.9 & 1.8 & 1.64 & 0.01 \\
\hline $20-30$ & 450.5 & 10.3 & 481.3 & 9.3 & 12.5 & 0.9 & 8.9 & 0.5 & 47.2 & 2.2 & 1.55 & 0.00 \\
\hline $30-60$ & 456.2 & 4.4 & 469.0 & 5.9 & 12.8 & 0.6 & 7.7 & 0.6 & 55.0 & 1.9 & 1.55 & 0.03 \\
\hline $60-90$ & 446.2 & 6.4 & 479.7 & 5.2 & 12.3 & 1.7 & 7.3 & 0.6 & 55.0 & 2.0 & 1.49 & 0.03 \\
\hline $90-120$ & 455.1 & 10.8 & 474.5 & 11.6 & 12.1 & 1.6 & 6.0 & 0.5 & 52.6 & 1.7 & 1.54 & 0.01 \\
\hline $120-150$ & 435.2 & 11.3 & 497.2 & 10.0 & 12.4 & 0.8 & 6.0 & 0.3 & 50.1 & 2.0 & 1.44 & 0.02 \\
\hline $150-180$ & 416.6 & 9.5 & 517.4 & 8.8 & 13.7 & 1.3 & 6.2 & 0.2 & 47.3 & 2.0 & 1.52 & 0.04 \\
\hline $180-210$ & 401.1 & 12.9 & 535.4 & 13.0 & 13.5 & 1.7 & 5.8 & 0.5 & 44.9 & 2.5 & 1.43 & 0.02 \\
\hline
\end{tabular}

Particle size data represents a mean of five cores.

SE, Standard error.

at $30 \mathrm{~cm}$ intervals. The samples were then bulked according to depth resulting in nine samples per plot. Soil bulk density samples were collected in duplicate using a $100 \mathrm{~cm}^{3}$ core from profile pits dug at the two sites and from the same depths as for particle size analysis. Because clay content increased with depth, especially at Banizoumbou, soil profiles at the two sites were divided into three horizons based on clay content resulting in the following depth intervals; $0-30 ; 30-120$; and $>120 \mathrm{~cm}$ at Bagoua; 0-30; 30-60; and $>60 \mathrm{~cm}$ at Banizoumbou. Composite samples for moisture retention were then collected from the three depth intervals at each site.

Particle size distribution was measured on the following fractions, 2000-200, 200-50, 50-20, 20-2, and <2 $\mu \mathrm{m}$ using the pipette method (Gee and Bauder, 1986). Measured soil bulk density and particle size data were used as input for ROSETTA, SOILPAR, and the Vauclin PTF to estimate the van Genuchten (Mualem, 1976; van Genuchten, 1980), Campbell (Campbell, 1974; Campbell and Norman, 1998), and Vauclin (Vauclin et al., 1983a) parameters respectively. The derived model para-

Table 3

Input parameters for moisture retention curves for Banizoumbou

\begin{tabular}{cllll}
\hline & Depth $(\mathrm{cm})$ & $0-30$ & $30-60$ & $>60$ \\
\hline Soil property & Sand $\left(\mathrm{g} \mathrm{kg}^{-1}\right)$ & 925.0 & 896.9 & 894.7 \\
& Silt $\left(\mathrm{g} \mathrm{kg}^{-1}\right)$ & 29.1 & 25.7 & 21.4 \\
& Clay $\left(\mathrm{g} \mathrm{kg}^{-1}\right)$ & 45.9 & 77.4 & 83.9 \\
& Bulk density $\left(\mathrm{g} \mathrm{cm}^{-3}\right)$ & 1.41 & 1.41 & 1.50 \\
van & $\theta_{\mathrm{r}}\left(\mathrm{cm}^{3} \mathrm{~cm}^{-3}\right)$ & 0.05 & 0.06 & 0.06 \\
& & $(0.0049)$ & $(0.0066)$ & $(0.0061)$ \\
& $\theta_{\mathrm{s}}\left(\mathrm{cm}^{3} \mathrm{~cm}^{-3}\right)$ & 0.42 & 0.42 & 0.40 \\
& & $(0.0062)$ & $(0.0079)$ & $(0.0065)$ \\
& $\alpha\left(\mathrm{cm}^{-1}\right)$ & 0.03 & 0.03 & 0.03 \\
& $L$ & $(0.0487)$ & $(0.0650)$ & $(0.0581)$ \\
& & 0.84 & 0.80 & 0.84 \\
& $n$ & $(0.4741)$ & $(0.5031)$ & $(0.5004)$ \\
& & 2.85 & 2.39 & 2.37 \\
& & $(0.0177)$ & $(0.0218)$ & $(0.0196)$ \\
& $K_{\mathrm{o}}\left(\mathrm{cm} \mathrm{d}^{-1}\right)$ & 23.74 & 21.14 & 17.22 \\
& & $(0.2294)$ & $(0.2358)$ & $(0.2364)$ \\
& $\psi_{\mathrm{e}}\left(-\mathrm{j} \mathrm{kg}{ }^{-1}\right)$ & 0.69 & 0.78 & 0.90 \\
& $b$ & 2.17 & 2.71 & 2.83 \\
& $K_{\mathrm{s}}\left(\mathrm{mm} \mathrm{h}^{-1}\right)$ & 73.43 & 56.65 & 42.94 \\
\hline
\end{tabular}

Estimation uncertainty for van Genuchten model parameter values in parentheses. meters were then used to model moisture retention curves using the van Genuchten and Campbell models, and $K$-theta curves using the van Genuchten, Campbell and Vauclin models. We then compared the modeled moisture retention curves with those determined on repacked soil cores in the lab using the hanging water column method (Klute, 1986) for low suction ranges $(0-6 \mathrm{kPa})$ and published pressure plate data for high suction ranges $(33,300$ and $1500 \mathrm{kPa})$ for Niger sandy soils with similar properties (Payne, 1987). We also compared $K-$ theta curves modeled by the van Genuchten, Campbell, and Vauclin functions to those derived using Klaij and Vachaud's method (Klaij and Vachaud, 1992) from neutron probe measurements in farmers' fields. Additionally, the root mean square error (RMSE) was computed between the modeled and field determined moisture retention and $K$-theta curves.

To measure the soil volumetric moisture content, aluminum access tubes were installed in the centers of $10 \times 10 \mathrm{~m}$ plots sown to pearl millet at both sites. Each plot had one access tube. Soil profile volumetric moisture content was then measured to a

Table 4

Input parameters for moisture retention curves for Bagoua

\begin{tabular}{cllll}
\hline & Depth $(\mathrm{cm})$ & $0-30$ & $30-120$ & $>120$ \\
\hline Soil property & Sand $\left(\mathrm{g} \mathrm{kg}^{-1}\right)$ & 941.5 & 926.7 & 934.0 \\
& Silt $\left(\mathrm{g} \mathrm{kg}^{-1}\right)$ & 22.4 & 19.1 & 19.0 \\
& Clay $\left(\mathrm{g} \mathrm{kg}^{-1}\right)$ & 36.1 & 54.2 & 47.0 \\
& Bulk density $\left(\mathrm{g} \mathrm{cm}^{-3}\right)$ & 1.58 & 1.53 & 1.46 \\
van & $\theta_{\mathrm{r}}\left(\mathrm{cm}^{3} \mathrm{~cm}^{-3}\right)$ & 0.05 & 0.06 & 0.06 \\
& & $(0.0040)$ & $(0.0043)$ & $(0.0052)$ \\
& $\theta_{\mathrm{s}}\left(\mathrm{cm}^{3} \mathrm{~cm}^{-3}\right)$ & 0.36 & 0.38 & 0.40 \\
& & $(0.0048)$ & $(0.0048)$ & $(0.0055)$ \\
& $\alpha\left(\mathrm{cm}^{-1}\right)$ & 0.03 & 0.03 & 0.03 \\
& & $(0.0347)$ & $(0.0384)$ & $(0.0451)$ \\
& & 0.91 & 0.90 & 0.88 \\
& $n$ & $(0.4945)$ & $(0.4664)$ & $(0.4613)$ \\
& & 3.19 & 2.91 & 3.05 \\
& & $(0.0131)$ & $(0.0134)$ & $(0.0181)$ \\
& & 19.91 & 17.95 & 20.35 \\
& & $(1.7624)$ & $(1.7140)$ & $(1.6869)$ \\
& & 0.75 & 0.79 & 0.71 \\
& & 1.97 & 2.25 & 2.13 \\
& & 61.39 & 56.27 & 68.98 \\
\hline
\end{tabular}

Estimation uncertainty for van Genuchten model parameter values in parentheses. 
Table 5

Input parameters for unsaturated hydraulic conductivity at $1.4 \mathrm{~m}$ soil depth for Banizoumbou and Bagoua

\begin{tabular}{llll}
\hline Model & Parameter & Banizoumbou & Bagoua \\
\hline van Genuchten & $L$ & $0.84(0.5128)$ & $0.87(0.4642)$ \\
& $N$ & $2.40(1.0481)$ & $2.98(1.0418)$ \\
\multirow{3}{*}{ Campbell } & $K_{\mathrm{o}}\left(\mathrm{cm} \mathrm{d}^{-1}\right)$ & $17.76(1.1768)$ & $20.70(1.6873)$ \\
& $\psi_{\mathrm{e}}\left(-\mathrm{j} \mathrm{kg}^{-1}\right)$ & 0.87 & 0.70 \\
\multirow{3}{*}{ Vauclin } & $b$ & 2.78 & 2.18 \\
& $K_{\mathrm{s}}\left(\mathrm{mm} \mathrm{h}^{-1}\right)$ & 46.28 & 70.03 \\
& $b$ & 7.50 & 5.90 \\
& $K_{\mathrm{o}}\left(\mathrm{cm} \mathrm{h}^{-1}\right)$ & 15.10 & 20.40 \\
\hline
\end{tabular}

Estimation uncertainty for van Genuchten model parameter values in parentheses.

depth, $Z_{\mathrm{m}}$, of $1.8 \mathrm{~m}$ in each of the plots using a field calibrated neutron probe (IH II Probe, Didcot Instrument Co., UK). A calibration curve was developed for each of the following depths; $0-15 \mathrm{~cm} ; 15-30 \mathrm{~cm}$ and $>30 \mathrm{~cm}$. Although neutron probes are known to lose resolution near the surface because of escaping neutrons (Holmes, 1956), satisfactory curves were obtained near the surface $\left(r^{2}=0.99\right.$ for $15 \mathrm{~cm} ; 0.98$ for both the $15-30 \mathrm{~cm}$ and $>30 \mathrm{~cm}$ depth). Soil volumetric moisture content (\%) was calculated by

$\theta_{\mathrm{v}}=a+b\left(C / C_{\mathrm{s}}\right)$,

where $\theta_{\mathrm{v}}$ is volumetric moisture content (\%); $a$ is the intercept of the calibration curve; $b$ is the slope of the curve; $C$ is the neutron count read by the neutron probe; and $C_{\mathrm{s}}$ is the standard count. The standard count was obtained at the beginning of each measurement date by taking a neutron probe reading in a drum full of pure water. The amount of water stored in the profile was calculated by the trapezoidal integration of the soil moisture content values over the depth of the profile. The accuracy of the trapezoidal estimates mainly depends on uncertainties associated with calibration (Vauclin et al., 1983b) and according to Klaij and Vachaud (1992) is typically $\pm 4 \mathrm{~mm}$ for $260 \mathrm{~mm}$ storage (profile at field capacity).

We directly estimated $K$ at the maximum rooting depth, $Z_{\mathrm{r}}$ $(1.4 \mathrm{~m})$ using the two stage method proposed by Klaij and Vachaud (1992). Knowledge of $K$ for this depth is needed to calculate root zone drainage and other soil water balance terms (Payne, 1997). In Klaij and Vachaud (1992), stage one represents the beginning of the season when the soil is wetting and the wetting front has not yet passed the bottom of the soil profile $(1.8 \mathrm{~m})$. Stage two is the period when the wetting front has reached the bottom of the profile. During stage one, if the moisture content between the maximum rooting depth $(1.4 \mathrm{~m})$ and the bottom of the profile $(1.8 \mathrm{~m}), S_{\mathrm{rm}}$, increases by $\triangle S$, then it is assumed that the same amount of water must have drained through that plane. A single $K$ vs $\theta$ value of the soil hydraulic function can be estimated using the following equation:

$K(\theta)_{\mathrm{a}}=-D_{\mathrm{r}} \nabla H \Delta t$

where $\theta_{\mathrm{a}}$ is the arithmetic mean of the soil water content at the beginning $\left(t=t_{1}\right)$ and end of the time interval $\left(t=t_{1}+\Delta t\right)$ measured at $Z=Z_{\mathrm{r}} ; D_{\mathrm{r}}$ is the same as $S_{\mathrm{rm}} ; \nabla H$ is the hydraulic head gradient, which was assumed to be $(-1)$ at both sites based on results from earlier work in the region (Hartmann and Gandah, 1982; Klaij and Vachaud, 1992). Vachaud et al. (1991) found excellent correlation between $K(\theta)$ functions obtained with and without the unit gradient assumption (i.e., with and without tensiometric data) for coarse soils of Côte d'Ivoire, Mali, and Senegal. We used Eq. (11) and repeated the calculation for several time intervals per neutron probe during stage one. The result was a set of $K$ values at different $\theta$, creating a linear regression line.
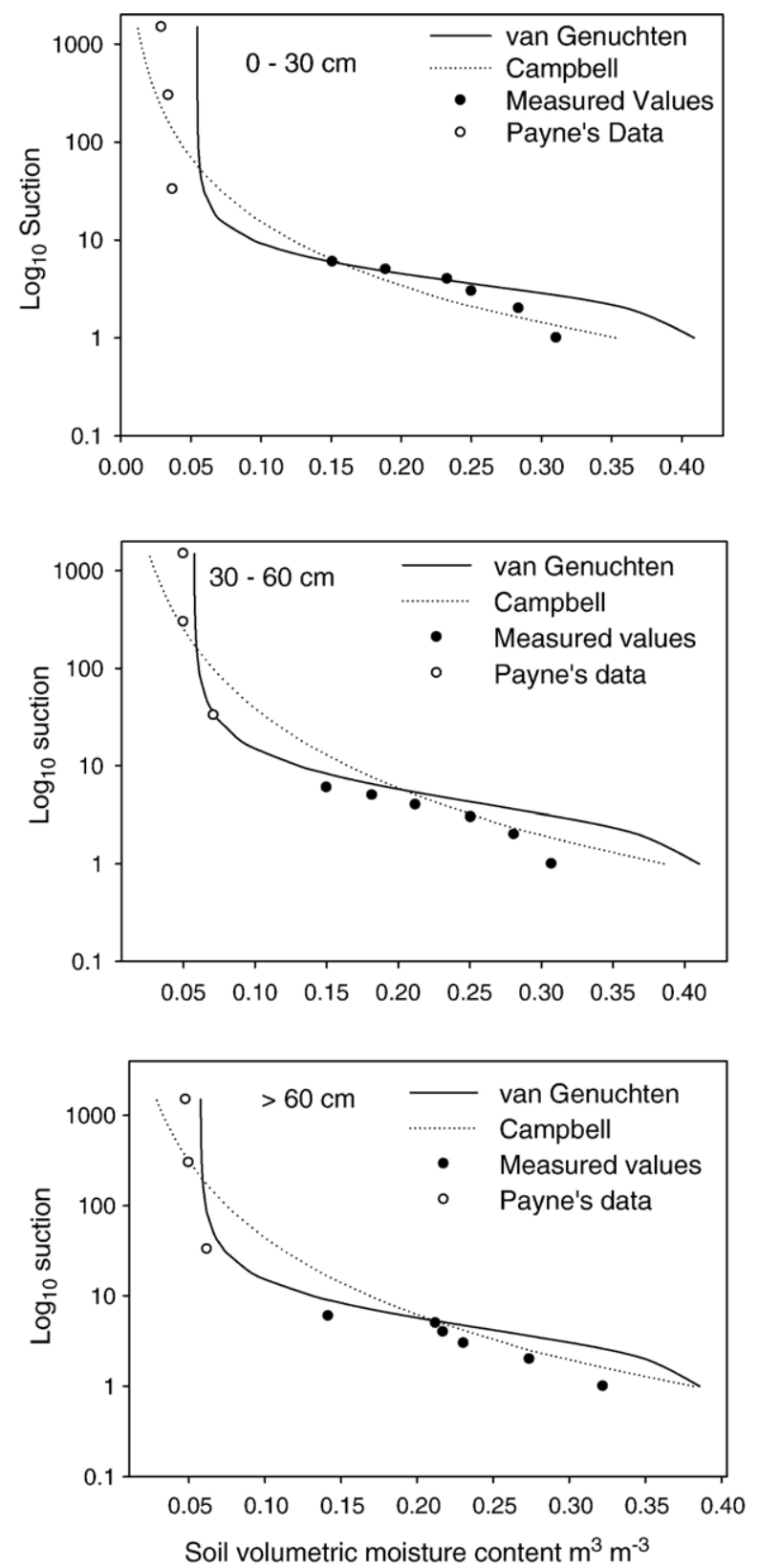

Fig. 1. Estimation of moisture retention curves by van Genuchten and Campbell models compared with measured values of the soil profile at Banizoumbou. Suction units are $\mathrm{kPa}$. 
The root mean square error was calculated as:

$\operatorname{RMSE}=\sqrt{\frac{1}{N} \sum_{i=1}^{n}\left(\xi_{i}-\xi_{i}^{\prime}\right)^{2}}$,

where $\xi_{i}$ is the measured value, $\xi_{i}{ }^{\prime}$ is the predicted value and $N$ is the number of data points.

\section{Results}

\subsection{Soil physical properties}

Tables 1 and 2 summarize the soil particle size distribution and bulk density data at the two sites. Generally, soil profile clay
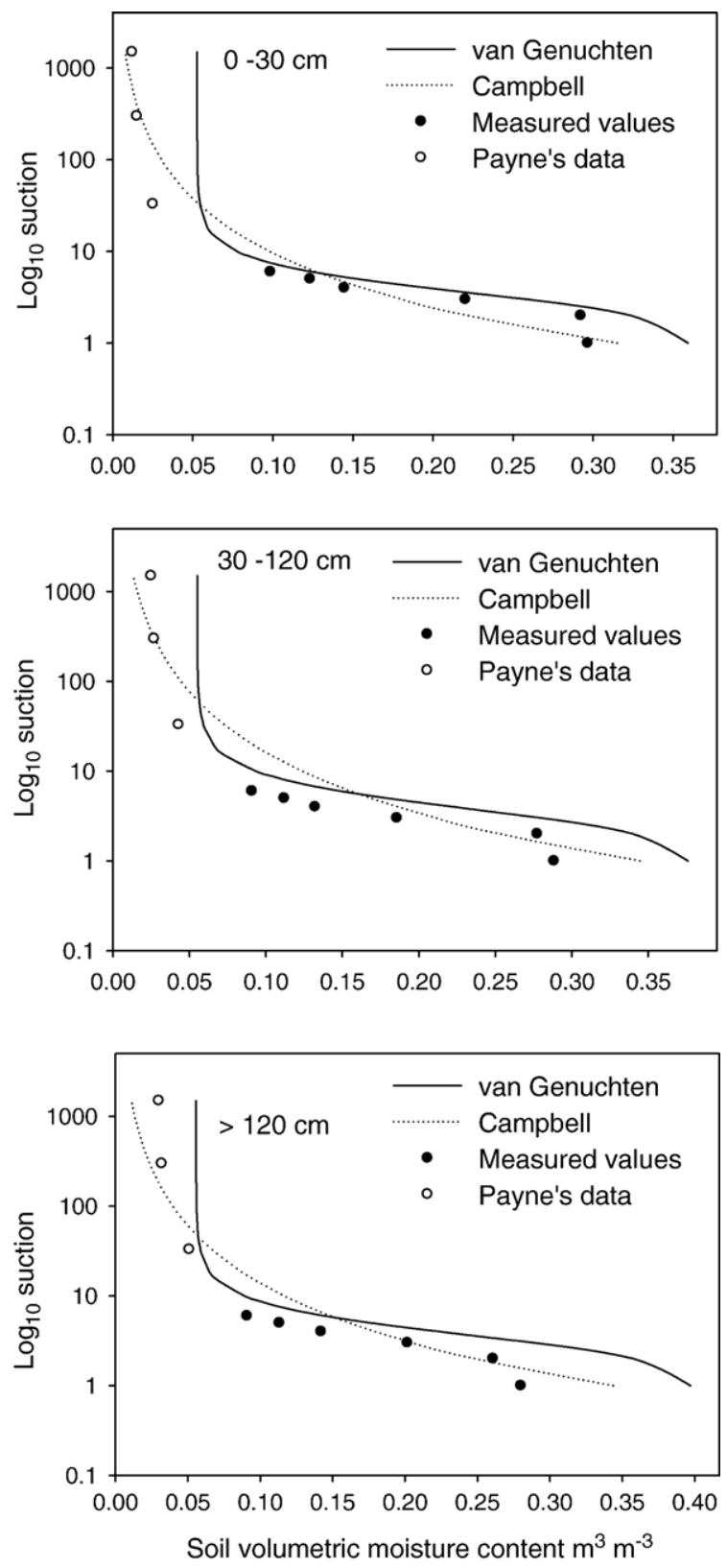

Fig. 2. Estimation of moisture retention curves by van Genuchten and Campbell models compared with measured values of the soil profile at Bagoua. Suction units are $\mathrm{kPa}$.

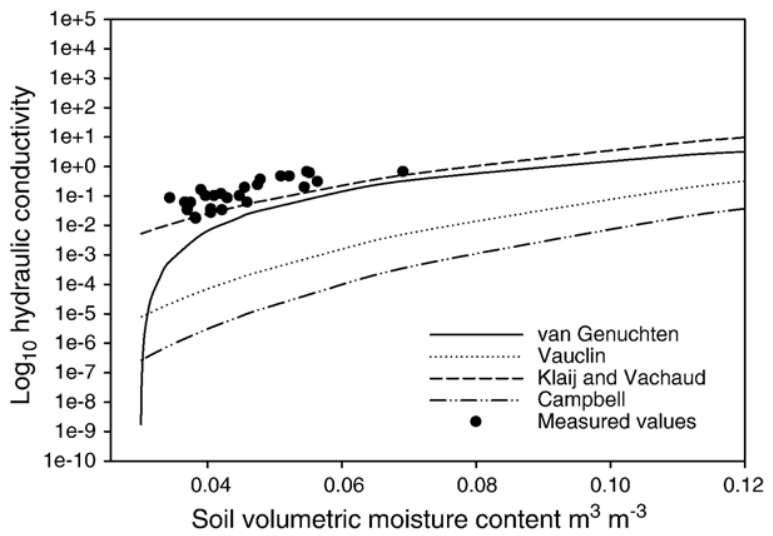

Fig. 3. Unsaturated hydraulic conductivity curves estimated by the van Genuchten, Campbell, and Vauclin models and compared with the Klaij and Vachaud field method for the $1.4 \mathrm{~m}$ soil depth at Banizoumbou. Unsaturated hydraulic conductivity units are $\mathrm{mm} \mathrm{d}^{-1}$.

content at the two sites was low, and did not reach $90 \mathrm{~g} \mathrm{~kg}^{-1}$ with Banizoumbou having higher clay content than Bagoua. At Banizoumbou bulk density was lower, possibly for two reasons, 1) higher clay content and 2) termite activity.

\subsection{Moisture retention curves}

The van Genuchten and Campbell model parameter values for moisture retention are presented in Tables 3 and 4 while those for $K$ are presented in Table 5. The moisture retention curves for the three depth intervals at the two sites (Figs. 1 and 2) are typical of the sandy soils which dominate most of southwestern Niger (Hoogmoed and Klaij, 1990; Payne et al., 1991). Field capacity of these soils ranges from anywhere between 0.12 and $0.16 \mathrm{~m}^{3} \mathrm{~m}^{-3}$ depending on clay content (Payne, 1987; Payne et al., 1990; Rockström et al., 1998). In this experiment, field capacity was reached at suctions $(\psi)$ below $10 \mathrm{kPa}$ similar to what Rockström et al. (1998) measured on similar soils in Niger and what Khaleel et al. (1995) reported for coarse sands in the Columbia Basin; as suction was increased to $50 \mathrm{kPa}$ the soils rapidly drained to $\theta<0.05 \mathrm{~m}^{3} \mathrm{~m}^{-3}$. For the sandy soils in this study, the moisture retention curves modeled by the van Genuchten model show a rapid decrease in moisture with little increase in suction and hence a low water holding capacity.

The Campbell model performed well for the $0-30 \mathrm{~cm}$ soil depth at Banizoumbou (Fig. 1), with a RMSE of $0.05 \mathrm{~m}^{3} \mathrm{~m}^{-3}$. For depths below $30 \mathrm{~cm}$, the Campbell model tended to overestimate $\psi$ for $\theta$ between 0.05 and $0.20 \mathrm{~m}^{3} \mathrm{~m}^{-3}$ and had a RMSE of 0.05 and $0.04 \mathrm{~m}^{3} \mathrm{~m}^{-3}$ for $30-60 \mathrm{~cm}$ and $>60 \mathrm{~cm}$ soil depth, respectively. The overestimation of $\psi$ at lower $\theta$ by the Campbell model was also reported for a Walla Walla silt loam soil under semi-arid conditions by Chen and Payne (2001). At the dry region of the moisture retention curve, the Campbell model predicted a more gradual change in $\theta$ with change in $\psi$, which is actually not typical of these sandy soils which have been shown to rapidly drain with small changes in $\psi$ (Hoogmoed and Klaij, 1990; Payne et al., 1991; Rockström et al., 1998). The van Genuchten model overestimated moisture retention in the dry region for the three 
depth intervals (Figs. 1 and 2) but performed well for the wet range especially for the $0-30$ and $30-60 \mathrm{~cm}$ depth intervals. The RMSE for the van Genuchten model for the 0-30 and 30-60 cm depth intervals at Banizoumbou was $0.07 \mathrm{~m}^{3} \mathrm{~m}^{-3}$, and for the $>60 \mathrm{~cm}$ depth interval it was $0.06 \mathrm{~m}^{3} \mathrm{~m}^{-3}$.

At Bagoua (Fig. 2), the Campbell model gave a good approximation of the moisture retention curve for the $0-30 \mathrm{~cm}$ soil depth interval, with an overall RMSE of $0.04 \mathrm{~m}^{3} \mathrm{~m}^{-3}$. The van Genuchten model also had an overall RMSE of $0.04 \mathrm{~m}^{3}$ $\mathrm{m}^{-3}$ for the $0-30 \mathrm{~cm}$ depth interval but it overestimated moisture content for the dry region of the curve. For the 30-120 and $>120 \mathrm{~cm}$ depth intervals, the Campbell model had an RMSE of $0.06 \mathrm{~m}^{3} \mathrm{~m}^{-3}$ and overestimated $\psi$ for $\theta$ between 0.05 and $0.15 \mathrm{~m}^{3} \mathrm{~m}^{-3}$. The van Genuchten model had an RMSE of 0.08 and $0.09 \mathrm{~m}^{3} \mathrm{~m}^{-3}$ for the 30-120 and $>120 \mathrm{~cm}$ depth intervals, respectively. As at Banizoumbou, the van Genuchten model tended to overestimate dry end $\theta$ while performing better for the wet end. Although the two models gave slightly different moisture retention curves, they both expose the low water holding capacity of the soils in the study sites, which is one of the challenges subsistence farmers in the region have to contend with for pearl millet production.

\subsection{Unsaturated hydraulic conductivity}

At Banizoumbou (Fig. 3), the van Genuchten model for $K$ was in excellent agreement with Klaij and Vachaud's field method (RMSE $0.26 \mathrm{~mm} \mathrm{~d}^{-1}$ ). The van Genuchten $K$ values ranged from 0 to $5.3 \mathrm{~mm} \mathrm{~d}^{-1}$ for $\theta$ values of 0.04 to $0.10 \mathrm{~m}^{3}$ $\mathrm{m}^{-3}$. For the same range in moisture, the Campbell and Vauclin models estimated negligible $K$ (RMSE 1.01 and $0.88 \mathrm{~mm} \mathrm{~d}^{-1}$ respectively). For $K$, we calculated RMSE only for moisture content values between 0.04 and $0.1 \mathrm{~m}^{3} \mathrm{~m}^{-3}$ to facilitate comparison of the three models (see Figs. 3 and 4) since moisture contents below $0.04 \mathrm{~m}^{3} \mathrm{~m}^{-3}$ would have greatly distorted the RMSE for the van Genuchten model.

At Bagoua (Fig. 4), the van Genuchten model underestimated $K$ (RMSE $0.47 \mathrm{~mm} \mathrm{~d}^{-1}$ ) for the drier soil range but was still

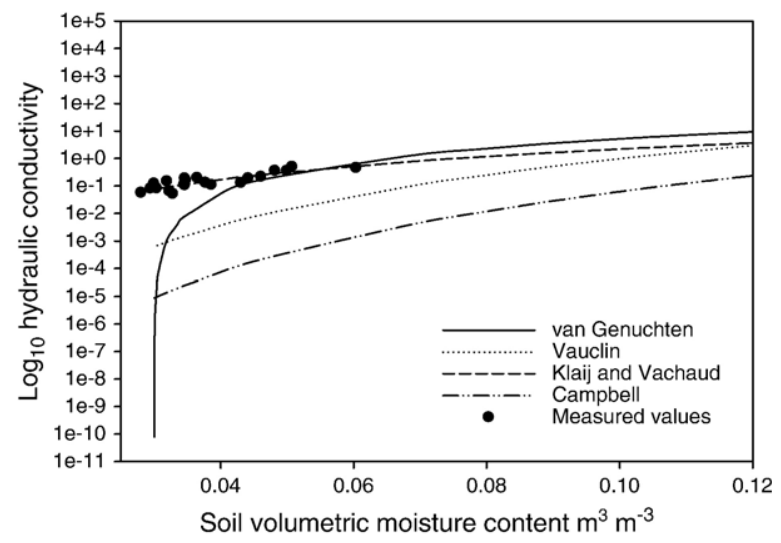

Fig. 4. Unsaturated hydraulic conductivity curves estimated by the van Genuchten, Campbell, and Vauclin models and compared with the Klaij and Vachaud field method for the $1.4 \mathrm{~m}$ soil depth at Bagoua. Unsaturated hydraulic conductivity units are $\mathrm{mm} \mathrm{d}^{-1}$. close to Klaij and Vachaud's field method. Payne (1987) also showed that at moisture contents below $0.05 \mathrm{~m}^{3} \mathrm{~m}^{-3}, K$ for these sandy soils is negligible. While underestimating $K$, and subsequently root zone drainage, for dry soils (e.g. when $\theta<0.05 \mathrm{~m}^{3}$ $\mathrm{m}^{-3}$ ) at our study sites may not be problematic, evapotranspiration (ET) can be overestimated in water balance calculations when $K$ is underestimated for wet soils or if the soils are at field capacity. At this site, the Klaij and Vachaud field method estimated $K$ ranging from 0.2 to $2.5 \mathrm{~mm} \mathrm{~d}^{-1}$ for soil moisture ranging from 0.04 to $0.10 \mathrm{~m}^{3} \mathrm{~m}^{-3}$. The Vauclin model estimated $K$ values from 0 to $1.3 \mathrm{~mm} \mathrm{~d}^{-1}$ (RMSE $0.61 \mathrm{~mm} \mathrm{~d}^{-1}$ ). Estimates of $K$ by the Klaij and Vachaud field method and the van Genuchten model at this site fall within the range of what has been previously reported for other sandy soils in the Sahel with similar properties (Klaij and Vachaud, 1992; Grema and Hess, 1994) whereas the Campbell model resulted in consistently lower $K$ (RMSE $0.91 \mathrm{~mm} \mathrm{~d}^{-1}$ ). From a management point of view, results from the three models generally show a rapidly decreasing $K$ with decreasing moisture content, which translates to low root zone drainage at low moisture content.

\section{Discussion and conclusion}

By using measured PSD and bulk density data to estimate PTF parameter values, we managed to estimate functional hydraulic properties for the study soils (moisture retention curve by the Campbell model and $K$ by the van Genuchten model) with reasonable accuracy. The Campbell model appeared to be better suited for estimating moisture retention for surface soils with high sand content at both locations. Meissner (2004) studied the relationship between soil properties of 294 soil samples in Australia and parameters of the Campbell and van Genuchten models. His soil samples had sand content ranging from 38.0 to $97.5 \%$, clay content ranging from 2.0 to $46.5 \%$, and silt content ranging from 0.5 to $18.0 \%$. He found that all the Campbell parameters were strongly related to soil properties especially the sand content and fine earth carbonate whereas only the $n$ parameter for the van Genuchten model showed any strong relationship to sand content. The author concluded that although both models were excellent in describing the functional relationship between the soil moisture content and matric suction, the Campbell model was more useful since its parameters were more strongly correlated with easily measured soil parameters. In this study, although the van Genuchten model consistently overestimated moisture retention at the dry regime, it resulted in better predictions for the wet regime at both sites and for all depth intervals (Figs. 1 and 2). The general disagreement between the van Genuchten and Campbell models was also reported for a Walla Walla silt loam soil under semi-arid conditions (Chen and Payne, 2001). The authors found that the Campbell model tended to estimate higher suction as moisture content decreased below $0.30 \mathrm{~m}^{3} \mathrm{~m}^{-3}$. The large difference in $\mathrm{Ks}$ values used by the two models (e.g. $23.74 \mathrm{~cm} \mathrm{~d}^{-1}$ for the van Genuchten model vs. $176.23 \mathrm{~cm} \mathrm{~d}^{-1}$ for the Campbell model at Banizoumbou) may have caused the discrepancy in the water retention curves. Given the labor, time and cost requirements for field measurements, the Campbell model can be a faster and cheaper alternative for estimating the moisture retention data. 
The $K$-theta curves derived from Klaij and Vachaud's direct method at both sites were similar to those derived from neutron probe readings and internal drainage experiments on similar soils in Niger (Hartmann and Gandah, 1982; Hoogmoed and Klaij, 1990; Payne et al., 1991) and in Senegal (Vachaud et al., 1978; Vauclin et al., 1983a). The van Genuchten model consistently estimated $K$ values similar to Klaij and Vachaud's direct method for the $1.4 \mathrm{~m}$ soil depth at both sites. The Campbell model on the other hand, underestimated $K$, making it a less likely candidate for modeling $K$ at the study sites or for similar soils because this may lead to underestimation of root zone drainage in water balance calculations. Wagner et al (2001) found that the performance of the Campbell model could be greatly improved when the particle size distribution data used in determining the Campbell parameters are as detailed as possible and not just the clay, silt and sand contents as used in this study. The Vauclin model underestimated $K$ especially for Banizoumbou which had higher clay content. On the contrary, the Vauclin model gave better results for the Bagoua soil which had higher sand content.

Although it has been generally accepted that the accuracy of PTFs tends to increase with an increase in the number of measured input parameters, this is not necessarily true. For example, in the study by Schaap et al. (2004) comparing a total of 11 water retention PTFs varying in amount of required input, the authors did not show an overall superior model. In their study, models with many calibration parameters were not necessarily better than the more simple models. In this study we only used measured soil texture and bulk density as PTF input and the resulting modeled soil hydraulic properties were comparable to the measured properties. Based on the results from this study, we can conclude that the van Genuchten, Campbell, and Vauclin PTFs can be used with minimum field measured input to model the hydraulic properties of sandy soils in Niger with reasonable accuracy.

\section{Acknowledgements}

The authors wish to thank ICRISAT (India) and USAID for funding this research. All soil analyses were done with the help of Mr. Ilyassou Oumarou at ICRISAT Sahelian Center in Niger.

\section{References}

Acutis, M., Donatelli, M., 2003. SOILPAR 2.00: software to estimate soil hydrological parameters and functions. Eur. J. Agron. 18, 373-377.

Amayreh, J., Al-Abed, N., Nassar, A., Massad, E., Alrousan, L., Amer, E.Z., 2003. Modeling soil water retention curves using van Genuchten's model for several agricultural soils in Jordan. Arch. Agron. Soil Sci. 49, 427-433.

Brooks, R.H., Corey, A.T., 1964. Hydraulic properties of porous media. Colorado State University Hydrol. Paper vol. 3, 27.

Campbell, G.S., 1974. A simple method for determining unsaturated conductivity from moisture retention data. Soil Sci. 117, 311-314.

Campbell, G.S., 1985. Soil Physics with BASIC: Transport Models for SoilPlant System. Elsevier, Amsterdam, p. 150.

Campbell, G.S., Norman, J.M., 1998. An Introduction to Environmental Biophysics, 2nd ed. Springer-Verlag, New York Inc.

Chen, C., Payne, W.A., 2001. Measured and modeled unsaturated hydraulic conductivity of a Walla Walla silt loam. Soil Sci. Soc. Am. J. 65, 1385-1391.

Cornelis, W.M., Ronsyn, J., van Meirvenne, M., Hartmann, R., 2001. Evaluation of pedotransfer functions for predicting the soil moisture retention curve. Soil Sci. Soc. Am. J. 65, 638-648.
Elsenbeer, H., 2001. Pedotransfer functions in hydrology. J. Hydrol. 251, 121-122. Gee, G.W., Bauder, J.W., 1986. Particle size analysis, In: Klute, A. (Ed.), Methods of Soil Analysis, Part 1. Physical and Mineralogical Methods, 2nd ed. ASA SSSA, Madison, WI, pp. 383-411.

Green, R.E., Ahuja, L.R., Chong, S.K., 1986. Hydraulic conductivity, diffusivity and sorptivity of unsaturated soils: field methods, In: Klute, A., Dinauer, R.C. (Eds.), Methods of Soil Analysis, 2nd ed. Part I. Agronomy Monographs, vol. 9. ASA, Madison, WI, pp. 493-544.

Grema, A.K., Hess, T.M., 1994. Water balance and water use of pearl milletcowpea intercrops in north east Nigeria. Agric. Water Manag. 26, 169-185.

Hartmann, R., Gandah, M., 1982. Hydrodynamic characterization of a sand dune soil in Niger. Meded. Fac. Landbouwwet. Rijksuniv. Gent 47, 1194-1204.

Haverkamp, R., Parlange, J.Y., 1986. Predicting the water-retention curve from particle size distribution: 1 . Sandy soils without organic matters. Soil Sci. $142,325-339$.

Heil, J.W., Juo, A.S.R., McInnes, K.J., 1997. Soil properties influencing surface sealing of some sandy soils in the Sahel. Soil Sci. 162, 459-469.

Hodnett, M.G., Tomasella, J., 2002. Marked differences between van Genuchten soil water-retention parameters for temperate and tropical soils: a new waterretention pedo-transfer functions developed for tropical soils. Geoderma $108,155-180$.

Holmes, J.W., 1956. Calibration and field use of the neutron scattering method for measuring soil water content. Aust. J. Appl. Sci. 7, 45-58.

Hoogmoed, H.B., Klaij, M.C., 1990. Soil management for crop production in the West African Sahel. I. Soil and climate parameters. Soil Tillage Res. 16, 85-103.

Hutson, J.L., Cass, A., 1987. A retentivity function for use in soil water simulation model. J. Soil Sci 38, 105-113.

Khaleel, R., Relyea, J.F., Conca, J.L., 1995. Evaluation of the van GenuchtenMualem relationship to estimate unsaturated hydraulic conductivity at low water contents. Water Resour. Res. 31, 2659-2668.

Klaij, M.C., Vachaud, G., 1992. Seasonal water balance of a sandy soil in Niger cropped with pearl millet, based on profile moisture measurements. Agric. Water Manag. 21, 313-330.

Klute, A., 1986. Water retention: laboratory methods, In: Klute, A. (Ed.), Methods of Soil Analysis. Part 1. Physical and Mineralogical Methods, 2nd ed. ASA SSSA, Madison, WI, pp. 635-662.

Le Barbe, L., Lebel, T., 1997. Rainfall climatology of the HAPEX-Sahel region during the years 1960-1990. J. Hydrol. 188-189, 43-73.

Mayr, T., Jarvis, N.J., 1999. Pedotransfer function to estimate soil water retention parameter for a modified Brooks-Corey type model. Geoderma 91, 1-9.

Meissner, T., 2004. Relationship between soil properties of Mallee soils and parameters of two moisture characteristics SuperSoil 2004. Proc. 3rd Australian New Zealand Soils Conf., 5-9 December, 2004. University of Sydney, Australia.

Minasny, B., McBratney, A.B., 2002. The neuro-m method for fitting neural network parametric pedotransfer functions. Soil Sci. Soc. Am. J. 66, 352-361.

Mualem, Y., 1976. A new model for predicting the hydraulic conductivity of unsaturated porous media. Water Resour. Res. 12, 513-522.

Payne, W.A. 1987. Water balance of sandy soils of Niger, West Africa. MS thesis. Texas A\&M University, College Station.

Payne, W.A., 1997. Managing yield and water use of pearl millet in the Sahel. Agron. J. 89, 481-490.

Payne, W.A., Wendt, C.W., Lascano, R.J., 1990. Root zone water balances of three low input millet fields in Niger, West Africa. Agron. J. 82, 813-819.

Payne, W.A., Lascano, R.J., Wendt, C.W., 1991. Physical and hydrological characterization of three sandy millet fields in Niger. p. 199-207. In Sivakumar, M.V.K., et al. (eds.), Soil water balance in the Sudano-Sahelian Zone: Proc. Int. Workshop, Niamey, Niger, February 1991. IAHS Publication No. 199. IAHS Press, Institute of Hydrology, Wallingford, UK.

Rawls, W.J., Brakensiek, D.L., 1989. Estimation of soil water retention and hydraulic properties. In: Morel, S. (Ed.), Unsatured Flow in Hydrologic Modeling. Theory and Pratice, Kluwer Academic Publishers, pp. 275-300.

Rawls, W.J., Brakensiek, D.L., Saxton, K.E., 1982. Estimation of soil water properties. Trans. ASAE 25, 1316-1320.

Rawls, W.J., Gimenez, D., Grossman, R., 1998. Use of texture, bulk density, and slope of the water retention curve to predict saturated hydraulic conductivity. Trans. ASAE 41, 983-988. 
Rockström, J., Jansson, P.-E., Barron, J., 1998. Seasonal rainfall partitioning under runon and runoff conditions on sandy soil in Niger: on-farm measurements and water balance modeling. J. Hydrol. 210, 68-92.

Schaap, M.G., 1999. Rosetta version 1.0. [Online]. Available at: http://www.ars. usda.gov/services/software/download.htm?softwareid=101 (verified 11 May 2006).

Schaap, M.G., Bouten, W., 1996. Modeling water retention curves of sandy soils using neural networks. Water Resour. Res. 32, 3033-3040.

Schaap, M.G., Leij, F.J., 1998. Using neural networks to predict soil water retention and soil hydraulic conductivity. Soil Tillage Res. 47, 37-42.

Schaap, M.G., Leij, F.J., 2000. Improved prediction of unsaturated hydraulic conductivity with the Mualem-van Genuchten model. Soil Sci. Soc. Am. J. 64, 843-851.

Schaap, M.G., Leij, F.J., van Genuchten, M.T., 2001. ROSETTA: a computer program for estimating soil hydraulic parameters with hierarchical pedotransfer functions. J. Hydrol. 251, 163-176.

Schaap, M.G., Nemes, A., van Genuchten, M.T., 2004. Comparison of models for indirect estimation of water retention and available water in surface soils. Vadose Zone J. 3, 1455-1463.

Sobieraj, J.A., Elsenbeer, H., Vertessy, R.A., 2001. Pedotransfer functions for estimating saturated hydraulic conductivity: implications for modeling storm flow generation. J. Hydrol. 251, 202-220.

Soil Survey Staff, 1975. Soil Taxonomy. Soil Conservation Service, US Department of Agriculture, Washington DC, USA.

Suleiman, A.A., Ritchie, J.T., 2001. Estimating saturated hydraulic conductivity from soil porosity. Am. Soc. Agric. Eng. 44, 235-239.

Tietje, O., Hennings, V., 1996. Accuracy of the saturated hydraulic conductivity prediction by pedo-transfer functions compared to the variability within FAO textural classes. Geoderma 69, 71-84.

Vachaud, G., Dancette, C., Sonko, S., Thony, J.L., 1978. Methods of field characterization of the hydrodynamic properties of an unsaturated soil. Ann. Agron. 29, 1-36.

Vachaud, G., Vauclin, M., Laty, R., 1991. Caractérisation hydrodynamique in situ de quelques sols soudano-sahéliens à l'aide d'un programme de calcul assisté par micro-ordinateur. p. 175-185. In Sivakumar, M.V.K., et al. (eds.), Soil water balance in the Sudano-Sahelian Zone. IAHS Publ. No 199. IAHS Press, Institute of Hydrology, Wallingford, Oxfordshire, UK. van Genuchten, M.T., 1980. A closed-form equation for predicting the hydraulic conductivity of unsaturated soils. Soil Sci. Soc. Am. J. 44, 892-898.

van Genuchten, M.T., Leij, F.J., 1992. On estimating the hydraulic conductivity properties of unsaturated soils. In: van Genuchten, M.T., et al. (Eds.), Indirect Methods for Estimating the Hydraulic Properties of Unsaturated Soils. Proc. Int. Workshop, Riverside, CA, 11-13 October, 1989. University of California, Riverside, CA, pp. 1-14.

Vauclin, M., Imbernon, J., Vachaud, G., 1983a. Comparative analysis of different methods for the determination of unsaturated hydraulic conductivity of North-Central Senegal soils (In French). Agron. Trop. 38, 186-197.

Vauclin, M., Imbernon, J., Vachaud, G., 1983b. Analyse des erreurs liées á l'utilisation de 1'humidimétre neutroniue. In Isotope and Radiation Techniques in Soil Physics and Irrigation Studies 1983. International Atomic Energy, Vienna, pp. 533-549. (In French).

Vereecken, H., Maes, J., Darius, P., Feyen, J., 1989. Estimating the soil moisture retention characteristic from texture, bulk density and carbon content. Soil Sci. 148, 389-403.

Wagner, B., Tarnawski, V.R., Hennings, V., Müller, U., Wessoleke, G., Plagge, R., 2001. Evaluation of pedo-transfer functions for unsaturated soil hydraulic conductivity using an independent data set. Geoderma 102, 275-297.

Warrick, A.W., Nielsen, D.R., 1980. Spatial variability of soil physical properties in the field. In: Hillel, D. (Ed.), Applications of Soil Physics. Academic Press, New York, pp. 319-344.

Watson, K.K., 1966. An instantaneous profile method for determining the hydraulic conductivity of unsaturated porous materials. Water Resour. Res. 1, 577-586.

Wilding, L.P., 1984. Spatial variability: its documentation, accommodation and implication in soil surveys. In: Nielsen, D.R., Bouma, J. (Eds.), Soil Spatial Variability. Pudoc, Wageningen, pp. 166-193.

Wösten, J.H.M., Finke, P.A., Jansen, M.J.W., 1995. Comparison of class and continuous pedotransfer functions to generate soil hydraulic characteristics. Geoderma 66, 227-237.

Wösten, J.H.M., Pachepsky, Y.A., Rawls, W.J., 2001. Pedotransfer functions: bridging the gap between available basic soil data and missing soil hydraulic characteristics. J. Hydrol. 251, 123-150. 